\title{
Grain Yield and Critical Yield Determining Component of Bread Wheat Varieties in Response to Sowing Dates
}

\section{Javed Iqbal $^{1}$, Ali Zohaib ${ }^{1 *}$, Muzzammil Hussain ${ }^{1}$, Iftikhar Ahmad ${ }^{1}$, Adnan Bashir ${ }^{1}$, Wardah Muzaffer ${ }^{2}$, Naeem Faisal ${ }^{1}$, Muhammad Tahir Latif ${ }^{1}$ and Sami Ullah ${ }^{1}$}

${ }_{1}^{1}$ Adaptive Research Farm, Gujranwala 52200, Pakistan; ${ }^{2}$ Sugarcane Research Institute, Ayub Agricultural Research Institute, Faisalabad 38000, Pakistan.

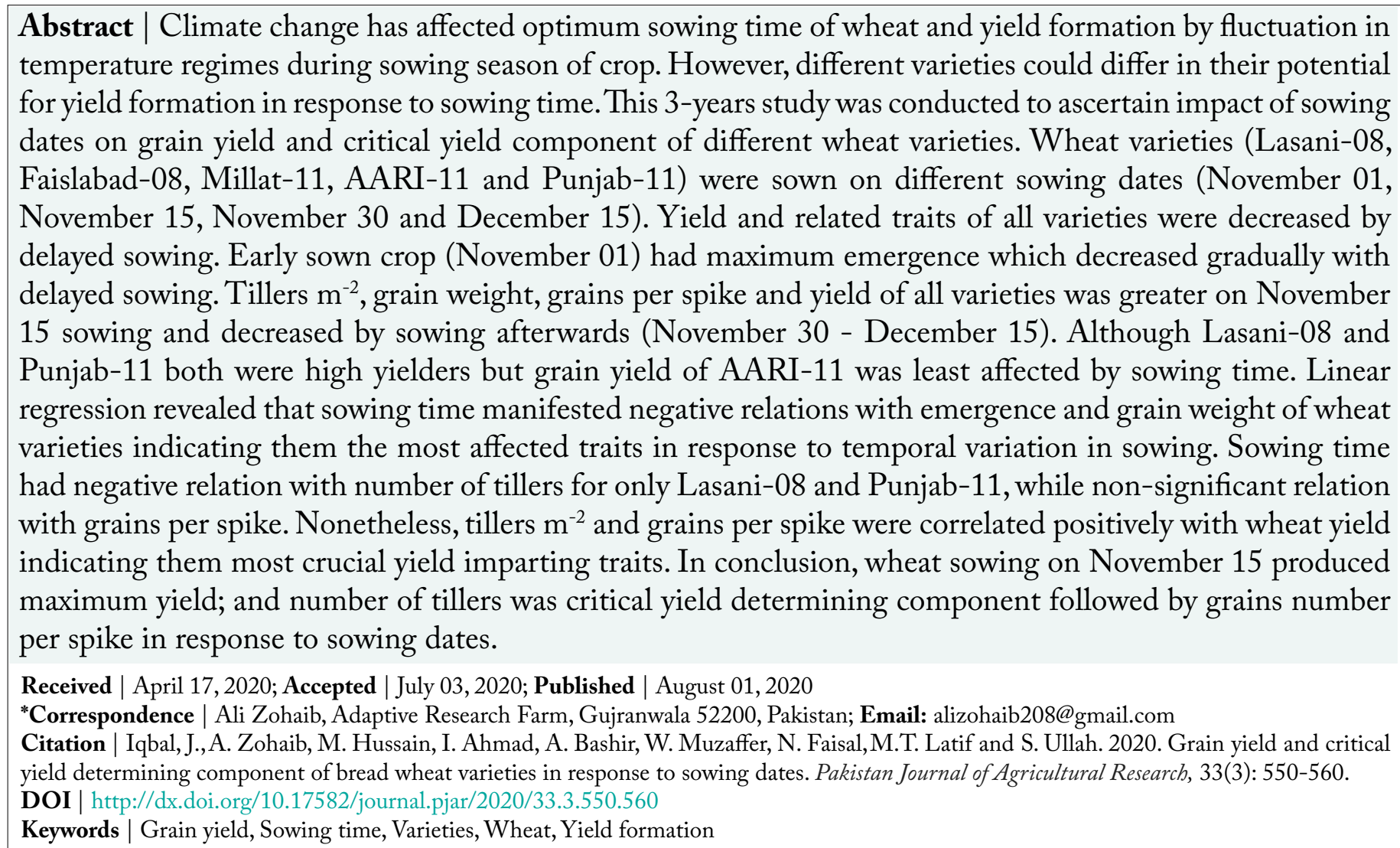

\section{Introduction}

$\mathrm{H}$ igh temperature is becoming an important limiting factor for crop productivity especially under the changing climate scenario and is projected to be increased up to $1.5-4.5^{\circ} \mathrm{C}$ by 2050 (Houghton et al., 2001). Wheat (Triticum aestivum L.) productivity is greatly influenced by temporal variation in sowing in rice-wheat cropping system in South Asian countries owing to variability in temperature regimes with respect to its phenophases (Fujisaka et al., 1994; Hussain et al., 2012a). Critical dates of wheat sowing than optimum exposes the crop to temperature extremes and consequences in altered heat unit accumulation and photoperiod which becomes limiting factor for yield (Arduini et al., 2009). This necessitates that management practices viz. time of sowing and selection of appropriate variety which could impose negative or positive effects on yield and yield formation must be studied for making better 
decisions (Sacks et al., 2010; Tapley et al., 2013).

Wheat sowing at optimum time is requisite to obtain high yield and potential benefits. Early sowing than optimum sowing time of wheat ensures better emergence and crop stand establishment; however, tiller production could decrease due to fluctuation in temperature and spike density in a defined area owing to inter-tiller competition (Hussain et al., 2012a; Tapley et al., 2013). Moreover, frost injury during anthesis could negatively influence the grains number per spike in too early sown wheat crop. On the other hand, late sowing negatively influences the stand establishment because of prevailing low temperature and decreases tillering capacity of plants (Farooq et al., 2008; Akhtar et al., 2012). Furthermore, heat stress during the anthesis as well as grain formation stage induces reduction in grains per spike by decreasing pollen viability and grain weight due to shortened duration and reduced grain filling rate (Prasad et al., 2008; Mohammed and Tarpley, 2010). In previous studies it has been reported that late sowing decreases emergence, tiller density, and grains number and weight of wheat ultimately decreasing grain yield (Wajid et al., 2004; Prasad et al., 2008; Akhtar et al., 2012; Tahir et al., 2019).

Proper selection of variety appropriate for specific sowing time is crucial to acquire high yield under the changing climatic conditions. Different varieties of wheat differ in their growth habit and yield formation with respect to sowing time and prevailing climatic conditions (Karim et al., 1999; Sandhu et al., 2019). The temperature is major factor which affects the wheat growth and productivity and requirement of temperature and/or growing degree days differ for different varieties (Hussain et al., 2012a). Sowing time influences the crop productivity mainly due to fluctuation in temperature and duration of growth period (Sandhu et al., 2019). For instance, higher yield could be achieved by early sowing of late maturing variety (Gomez-MacPherson and Richards, 1995); however, delayed sowing of late maturing variety results in decreased tillers due to shortening of growing period, and grains number and weight because of high temperature prevailing during anthesis and grain formation (Silva et al., 2014). Previous studies have reported differential responses of different varieties of wheat to sowing time (Bassu et al., 2010; Bagulho et al., 2015; Luo et al., 2018).
Grain yield of wheat could be divided into individual yield components of the tiller density, grain weight and number per spike. However, controversy exists regarding cruciality of different yield forming components in yield determination under the influence of different ecological and management factors (Thorne and Wood, 1987; Blue et al., 1990; Arduini et al., 2009; Friend, 2011). Sowing time substantially affects yield traits of wheat due to variation in temperature regarding various growth stages of crop (Sun et al., 2007; Bassu et al., 2010; Hussain et al., 2012a); however, clear understanding is required whether which yield component could become the crucial for determination of yield in response to sowing time for proper management decisions (Ortiz-Monasterio et al., 1994; Bassu et al., 2010). Previous reports have shown that there exist significant relationships between sowing time and different yield components but such relationships may differ for different varieties (Ortiz-Monasterio et al., 1994; Gomez-MacPherson and Richards, 1995). Although little attention has been given to quantitative relation of sowing time with yield formation; however, quantification of such relations could be crucial for crop management in context of thermo-temporal variation in sowing of wheat (Tapley et al., 2013).

Impact of the sowing dates on yield formation of wheat varieties was studied in three years two-factor factorial experiment. Objectives of the study were to (1) assess impact of dates of sowing on yield and related attributes of different wheat varieties (2) determine the quantitative relationship of sowing dates with yield attributes of wheat varieties and (3) elucidate the critical yield determining component of wheat in response to sowing dates.

\section{Materials and Methods}

\section{Experimental details}

The three years experiment was performed at Adaptive Research Farm, Gujranwala, Pakistan to ascertain impact of dates of sowing on yield formation of various wheat varieties during 2011-12 to 2013-14. Prior to sowing of crop, the soil samples drawn from depth of 0-30 cm. Working soil samples were submitted to Soil and Water Testing Laboratory, Gujranwala to determine the physico-chemical properties. Soil was heavy loam, having organic matter $1.06 \%$, pH 8.0 , electrical conductivity $1.38 \mathrm{dS} \mathrm{m} \mathrm{m}^{-1}$, total $\mathrm{N}$ 
$0.065 \%$, available $\mathrm{P} 12.7 \mathrm{ppm}$ and available K 177 ppm. Meteorological data prevailing during growing seasons of wheat experimentations are given in Table 1.

The experiment was performed by using the randomized complete block design with split plot arrangement and replicated thrice. The randomization of sowing dates was carried out in main plots and the varieties in sub plots. Net plot size of $3 \times 8 \mathrm{~m}^{2}$ was used. The treatments were comprised of different dates of sowing and wheat varieties. Sowing dates included November 01, November 15, November 30 and December 15 while wheat varieties tested were Lasani-2008, Faisalabad-2008 (FSD-08), Millat-2011, AARI-2011 and Punjab-2011 (PB-11).

\section{Crop busbandry}

The sowing of all wheat varieties was carried out on sowing dates as per treatments. Seed rate was kept $125 \mathrm{~kg} / \mathrm{ha}$ and treated with thiophenate methyl @ $3 \mathrm{~g} / \mathrm{kg}$ seed before sowing. Inter-row spacing was maintained at $22.5 \mathrm{~cm}$ while within rows the plants were sown continuously. The NPK (115-85-62 kg/ ha) was applied using urea ( $\mathrm{N} 46 \%$ ), diammonium phosphate ( $\left.\mathrm{N} 18 \%, \mathrm{P}_{2} \mathrm{O}_{5} 46 \%\right)$ and sulphate of potash $\left(\mathrm{K}_{2} \mathrm{O} 50 \%\right)$. Complete $\mathrm{P}, \mathrm{K}$ dose and half $\mathrm{N}$ were applied at sowing while remaining $\mathrm{N}$ was applied at first irrigation. Irrigations were applied according to soil and weather conditions. In total, two irrigations were applied during all years. Local recommended plant protection measures were adopted to control weeds, insects and diseases. The crop was harvested and threshed manually during first week of May during all years.

\section{Observations}

The data were collected regarding yield formation and grain yield of wheat. Emergence was noted by counting plants $\mathrm{m}^{-2}$ after the completion of emergence in all replications. Productive tillers $\mathrm{m}^{-2}$ were counted at harvest. Afterwards, five spikes collected randomly from each replication were manually threshed and grains were counted and averaged to determine the grains number per spike. The 1000 grains were counted and weighed from each replication to determine 1000 -grain weight. The yield was quantified by manually harvesting and threshing crop $\mathrm{m}^{-2}$ from each replication and expressed in $\mathrm{tha}^{-1}$.

\section{Statistical analyses}

The data were checked for normality using the scatter plot technique and found normal. The year effect was found significant for studied traits and therefore analyzed and expressed separately. Fisher's analysis of variance (ANOVA) technique was used for statistical analyses of data (Steel et al., 1997). Least significance difference (LSD) test was used to compare the treatments' means at 5\% probability. Linear regression analysis was performed to assess relationship of sowing time with yield attributes (emergence count, tillers $\mathrm{m}^{-2}$, grains number per spike and thousand grains weight) of wheat to determine the impact of time of sowing on yield formation of each variety. Pearson's coefficients were computed to find out correlation of yield attributes with grain yield of wheat to assess the critical yield determining component in response to sowing time.

\section{Results and Discussion}

\section{Stand establishment}

Emergence count was gradually decreased by delayed sowing of all varieties during all years. Across varieties, highest emergence occurred on November 01 sowing. The greatest decrease in emergence on November 15 sowing was exhibited by FSD-08 during 2011-12 and 2012-13, and AARI-11 during 2013-14. Millat-11 showed highest decrease on both November 30 as well as December 15 sowing during 2011-12 and 201213. However, during 2013-14, highest reduction was observed for AARI-11 and Lasani-08 on November 30 and December 15 sowing, respectively. Among varieties Lasani-08 had the highest emergence count at all sowing dates during all years (Table 2). The reduction in emergence might be due to decline in temperature upon late sowing. Emergence and crop stand establishment is significantly affected by temperature (Hussain et al., 2012a). Late sowing results in decrease in air and soil temperature during early growth stages of wheat which causes a reduction in emergence and stand establishment (Jame and Cutforth, 2004). Previous studies have reported similar impact of temperature on emergence of crops (Hussain et al., 2012a; Shah et al., 2017).

\section{Grain yield and related attributes}

Highest tillers $\mathrm{m}^{-2}$ were noticed on November 15 sowingduring2011-12 and 2013-14, and on November 01 during 2012-13; whereas, decreased by sowing afterwards. On November 15 sowing, maximum increase in number of tillers was exhibited by Millat-11 during all the years. On November 30 sowing, 
Table 1: Meteorological conditions during wheat growing seasons.

\begin{tabular}{|c|c|c|c|c|c|c|c|c|c|c|c|c|}
\hline \multirow[t]{3}{*}{ Month } & \multirow{2}{*}{\multicolumn{3}{|c|}{ Total Rainfall (mm) }} & \multicolumn{9}{|c|}{ Temperature $\left({ }^{\circ} \mathrm{C}\right)$} \\
\hline & & & & \multicolumn{3}{|c|}{ Monthly Maximum } & \multicolumn{3}{|c|}{ Monthly Minimum } & \multicolumn{3}{|c|}{ Daily Mean } \\
\hline & 2011-12 & 2012-13 & 2013-14 & 2011-12 & $2012-13$ & 2013-14 & $2011-12$ & $2012-13$ & 2013-14 & 2011-12 & $2012-13$ & 2013-14 \\
\hline November & 1.0 & 0.0 & 2.0 & 28.0 & 27.8 & 25.0 & 13.0 & 11.5 & 10.5 & 20.5 & 19.7 & 19.3 \\
\hline December & 0.0 & 28.8 & 0.0 & 22.1 & 19.4 & 19.4 & 8.4 & 6.1 & 6.3 & 15.3 & 12.8 & 17.4 \\
\hline January & 25.6 & 27.7 & 6.0 & 17.8 & 15.9 & 16.6 & 3.6 & 4.6 & 4.9 & 10.7 & 10.3 & 13.7 \\
\hline February & 9.9 & 84.6 & 13.3 & 19.2 & 19.3 & 19.2 & 3.9 & 8.7 & 6.8 & 11.6 & 14.0 & 14.4 \\
\hline March & 23.0 & 23.4 & 48.5 & 27.0 & 26.6 & 24.1 & 12.0 & 12.7 & 11.0 & 19.5 & 19.7 & 21.8 \\
\hline April & 57.7 & 16.3 & 55.0 & 32.2 & 33.1 & 31.7 & 16.7 & 16.8 & 15.8 & 24.5 & 25.0 & 28.1 \\
\hline
\end{tabular}

Source: Meteorological Department, Punjab.

Table 2: Effect of sowing time on emergence, number of tillers, 1000-grain weight and number of grains per spike of wheat.

\begin{tabular}{|c|c|c|c|c|c|c|c|c|c|c|c|c|}
\hline \multirow[t]{2}{*}{ Treatments } & Nov 01 & Nov 15 & Nov 30 & Dec 15 & Nov 01 & Nov 15 & Nov 30 & Dec 15 & Nov 01 & Nov 15 & Nov 30 & Dec 15 \\
\hline & \multicolumn{4}{|c|}{ 2011-12 } & \multicolumn{4}{|c|}{ 2012-13 } & \multicolumn{4}{|c|}{ 2013-14 } \\
\hline
\end{tabular}

Emergence count $\mathrm{m}^{-2}$

Faisalabad-2008 $251.7 \mathrm{de} 238.3 \mathrm{~h} \quad 230.3 \mathrm{j} \quad 223.0 \mathrm{k} \quad 250.0 \mathrm{c} \quad 233.3 \mathrm{fg} \quad 224.7 \mathrm{hi} \quad 217.0 \mathrm{jk} \quad 225.3 \mathrm{c} \quad 217.7 \mathrm{de} \quad 216.0 \mathrm{e} \quad 196.0 \mathrm{~h}$ Lasani-2008 $\quad 268.0$ a $\quad 258.7$ bc 248.7 ef $\quad 245.0 \mathrm{fg} \quad 262.7$ a $\quad 253.7$ bc $\quad 243.0$ d $\quad 240.0$ de $\quad 244.7$ a $\quad 235.7$ b $\quad 236.0$ b $\quad 206.3 \mathrm{f}$ AARI-2011 $262.7 \mathrm{~b} \quad 255.0 \mathrm{~cd} \quad 237.0 \mathrm{~h} \quad 235.0 \mathrm{hi} \quad 257.7 \mathrm{~b} \quad 249.7 \mathrm{c} \quad 231.3 \mathrm{~g} \quad 228.7 \mathrm{gh} \quad 241.0 \mathrm{ab} \quad 223.3 \mathrm{~cd} \quad 221.7 \mathrm{cde} \quad 204.7 \mathrm{f}$

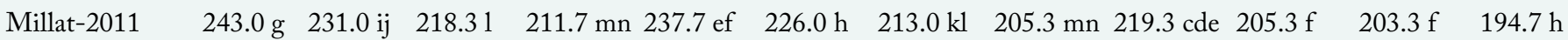

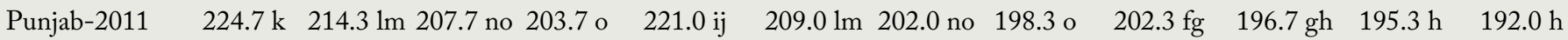

Number of tillers $\mathrm{m}^{-2}$

Faisalabad-2008 350.0 e $\quad 378.7$ d $\quad 319.3$ gh $\quad 323.7$ fg $\quad 341.0$ e $\quad 348.7$ e $\quad 309.3$ f-i $\quad 297.3$ ij $\quad 339.0 \mathrm{~cd} \quad 354.3$ bc $\quad 325.3 \mathrm{cde} \quad 282.3 \mathrm{fg}$

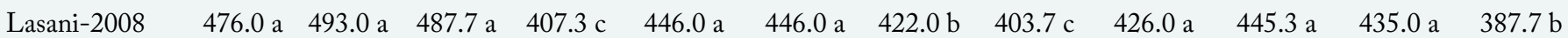

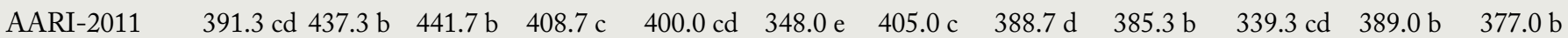
Millat-2011 $\quad 321.0 \mathrm{fg} \quad 378.3 \mathrm{~d} \quad 321.3 \mathrm{fg} \quad 309.7 \mathrm{gh} \quad 310.0 \mathrm{fgh} \quad 318.0 \mathrm{f} \quad 304.7 \mathrm{ghi} 280.0 \mathrm{k} \quad 302.3 \mathrm{efg} \quad 336.7 \mathrm{cde} \quad 317.3 \mathrm{def} \quad 273.7 \mathrm{~g}$ Punjab-2011 $\quad 350.0$ e $\quad 343.3$ ef $\quad 312.3$ gh 296.3 h $\quad 337.7$ e $\quad 315.3 \mathrm{fg} \quad 299.3 \mathrm{hi} \quad 286.7 \mathrm{jk} \quad 323.0 \mathrm{cde} \quad 312.7 \mathrm{def} \quad 281.3 \mathrm{fg} \quad 273.7 \mathrm{~g}$ 1000 -grain weight (g)

\begin{tabular}{|c|c|c|c|c|c|c|c|c|c|c|c|c|}
\hline Faisalabad-2008 & $40.9 \mathrm{bc}$ & $40.3 \mathrm{bcd}$ & $35.4 \mathrm{fgh}$ & $35.0 \mathrm{gh}$ & $36.9 c$ & $36.0 \mathrm{e}$ & $32.5 \mathrm{ij}$ & $32.1 \mathrm{kl}$ & $36.4 \mathrm{ab}$ & $35.9 \mathrm{a}$ & $32.4 \mathrm{~d}-\mathrm{g}$ & $32.0 \mathrm{fgh}$ \\
\hline Lasani-2008 & $36.4 \mathrm{fg}$ & $36.1 \mathrm{fgh}$ & $35.7 \mathrm{fgh}$ & $34.9 \mathrm{gh}$ & $32.3 \mathrm{jk}$ & $33.2 \mathrm{~g}$ & $32.7 \mathrm{hi}$ & $31.6 \mathrm{~m}$ & $32.1 \mathrm{fgh}$ & $33.2 \mathrm{~d}$ & $32.7 \mathrm{def}$ & $31.6 \mathrm{gh}$ \\
\hline ARI-2011 & $39.3 \mathrm{~cd}$ & $38.8 \mathrm{de}$ & $34.8 \mathrm{gh}$ & $34.4 \mathrm{~h}$ & $36.3 \mathrm{de}$ & $34.8 \mathrm{f}$ & 32.01 & $31.5 \mathrm{~m}$ & $36.2 \mathrm{ab}$ & $34.7 \mathrm{c}$ & $32.0 \mathrm{fgh}$ & $31.4 \mathrm{~h}$ \\
\hline Millat-2011 & $41.6 \mathrm{~b}$ & $41.2 \mathrm{~b}$ & $37.2 \mathrm{ef}$ & $37.1 \mathrm{ef}$ & $37.9 \mathrm{a}$ & $37.2 \mathrm{~b}$ & $33.1 \mathrm{~g}$ & $33.0 \mathrm{gh}$ & $36.5 \mathrm{ab}$ & $37.1 \mathrm{a}$ & $33.0 \mathrm{de}$ & $32.8 \mathrm{def}$ \\
\hline injab-2011 & $43.5 \mathrm{a}$ & $40.3 \mathrm{bcd}$ & $36.2 \mathrm{fgh}$ & $36.0 \mathrm{fgh}$ & $36.8 \mathrm{c}$ & $36.4 \mathrm{~d}$ & $32.3 \mathrm{jk}$ & $32.3 \mathrm{jk}$ & & $36.3 \mathrm{ab}$ & & $32.3 \mathrm{e}-\mathrm{h}$ \\
\hline \multicolumn{13}{|c|}{ Number of grains per spike } \\
\hline isalabad-2008 & $37.4 \mathrm{bcd}$ & $37.4 \mathrm{bcd}$ & $38.6 \mathrm{~b}$ & $36.8 \mathrm{cde}$ & $36.4 \mathrm{~d}-\mathrm{g}$ & $38.3 \mathrm{bc}$ & $38.6 \mathrm{bc}$ & $35.7 \mathrm{efg}$ & $35.30 \mathrm{def}$ & $37.33 \mathrm{a}-\mathrm{d}$ & $37.33 \mathrm{a}-\mathrm{d}$ & $36.47 b-f$ \\
\hline Lasani-2008 & $32.6 \mathrm{hi}$ & $34.9 \mathrm{fg}$ & $32.7 \mathrm{hi}$ & $32.0 \mathrm{i}$ & $33.2 \mathrm{~h}$ & $35.0 \mathrm{~g}$ & $30.7 \mathrm{j}$ & $31.1 \mathrm{ij}$ & $32.50 \mathrm{ghi}$ & $33.83 \mathrm{fgh}$ & $30.80 \mathrm{i}$ & $31.43 \mathrm{hi}$ \\
\hline AARI-2011 & $36.2 \mathrm{def}$ & $36.6 \mathrm{cde}$ & 36.0 def & $36.0 \mathrm{def}$ & $33.2 \mathrm{~h}$ & $37.8 \mathrm{bcd}$ & $35.2 \mathrm{fg}$ & $32.6 \mathrm{hi}$ & $34.43 \mathrm{efg}$ & $38.35 \mathrm{ab}$ & $35.20 \mathrm{def}$ & $34.00 \mathrm{fgh}$ \\
\hline Iillat-2011 & $34.6 \mathrm{fg}$ & $36.2 \mathrm{def}$ & $37.8 \mathrm{bc}$ & $34.0 \mathrm{gh}$ & $35.8 \mathrm{efg}$ & $36.0 \mathrm{efg}$ & 37.3 cde & $35.3 \mathrm{fg}$ & $35.50 \mathrm{def}$ & $35.50 \mathrm{def}$ & $35.67 \mathrm{c}-\mathrm{f}$ & $35.00 \mathrm{~d}-\mathrm{g}$ \\
\hline injab-2011 & 35.7 ef & $40.7 \mathrm{a}$ & $40.3 \mathrm{a}$ & $35.3 \mathrm{efg}$ & 37.3 cde & $40.3 \mathrm{a}$ & $39.3 \mathrm{ab}$ & $36.7 \mathrm{def}$ & $36.87 \mathrm{a}-\mathrm{e}$ & $39.38 \mathrm{a}$ & $39.00 \mathrm{ab}$ & $38.33 \mathrm{abc}$ \\
\hline
\end{tabular}
Means followed by different letters for a parameter during a specific year are significantly different at $P<0.05 ;$ Nov.: November, Dec.: December.

the greatest decrease in number of tillers was noticed for PB-11 during all the years. However, on December 15 sowing, PB-11 showed the highest decrease in number of tillers during 2011-12 and 2012-13, while FSD-08 during 2013-14. Among varieties, Lasani-08 produced highest number of tillers at all sowing dates during all years (Table 2). Highest 1000-grain weight of all varieties was attained upon sowing on November 01, during all years and decreased by sowing afterwards. The PB-11 showed the greatest decrease in 1000-grain weight during 2011-12 and AARI-11 during 2012-13 as well as 2013-14 by sowing after November 01, during all the years. Moreover, on November 01 sowing the heaviest 
grains were produced by PB-11 during 2011-12 and 2013-14, and Millat-11 during 2012-13. However, on November 15 and 30, as well as December 15 sowing Millat-11 produced heaviest grains during all the years (Table 2).

Grains number per spike was increased by sowing on November 15 as well as 30 , while decreased by December 15 sowing. On November 15 sowing, maximum increase in grains per spike occurred in PB11 during 2011-12 while AARI-11 during 2012-13 and 2013-14. On November 30 sowing, the greatest increase in grains per spike was noticed in PB-11, AARI-11 and FSD-08 during 2011-12, 2012-13 and 2013-14, respectively. On December 15 sowing, maximum decline in grains per spike occurred in Lasani-08 during all the years, while, FSD-08 and Millat-11 during 2011-12. Among varieties highest grains per spike were formed by PB-11 during all the years (Table 2). Grain yield of all varieties was highest on November 15 sowing, while started declining upon sowing afterwards. However, Lasani-08 and AARI-11 showed higher grain yield on November 30 sowing, as compared to November 01 sowing, during 2011-12 and 2013-14. In addition, grain yield of all wheat varieties sown on December 15 was reduced except AARI-11 during 2011-12 and Lasani-08 during 2013-14, as compared to November 01 sown crop. Among varieties, Lasani-08 was high yielder during 2011-12 while PB-11 during 2012-13 and 2013-14 at all sowing dates (Figure 1).

In present study, maximum yield of all varieties of wheat was obtained by November 15 sowing (Figure 1 ). The declined yield in response to early or late sowing is attributed to decrease in tillers $\mathrm{m}^{-2}$, grain weight and grains number per spike (Table 2; Figure 1). In present study, early and late sowing might have decreased number of tillers because of unfavorable temperature prevailing during tillering (Qasim et al., 2008; Hussain et al., 2012b; Tahir et al., 2019). Declined grain weight in response to late sowing may be accredited to decreased grain filling duration and high temperature during reproductive stage which decreases enzyme activity and rate of grain filling (Wallwork et al., 1998; Barnabás et al., 2008; Hussain et al., 2012a). The decrease in grains per spike in early sown crop may be because of frost injury during flowering while in late sown crop because of reduced spikelets per spike and pollen viability in response to heat stress (Arduini et al., 2009; Mohammed and
Tarpley, 2010; Tahir et al., 2019). Previous studies support our results pertaining to yield and related attributes of wheat due to sowing time (Inamullah et al., 2007; Baloch et al., 2010; Lan et al., 2018).
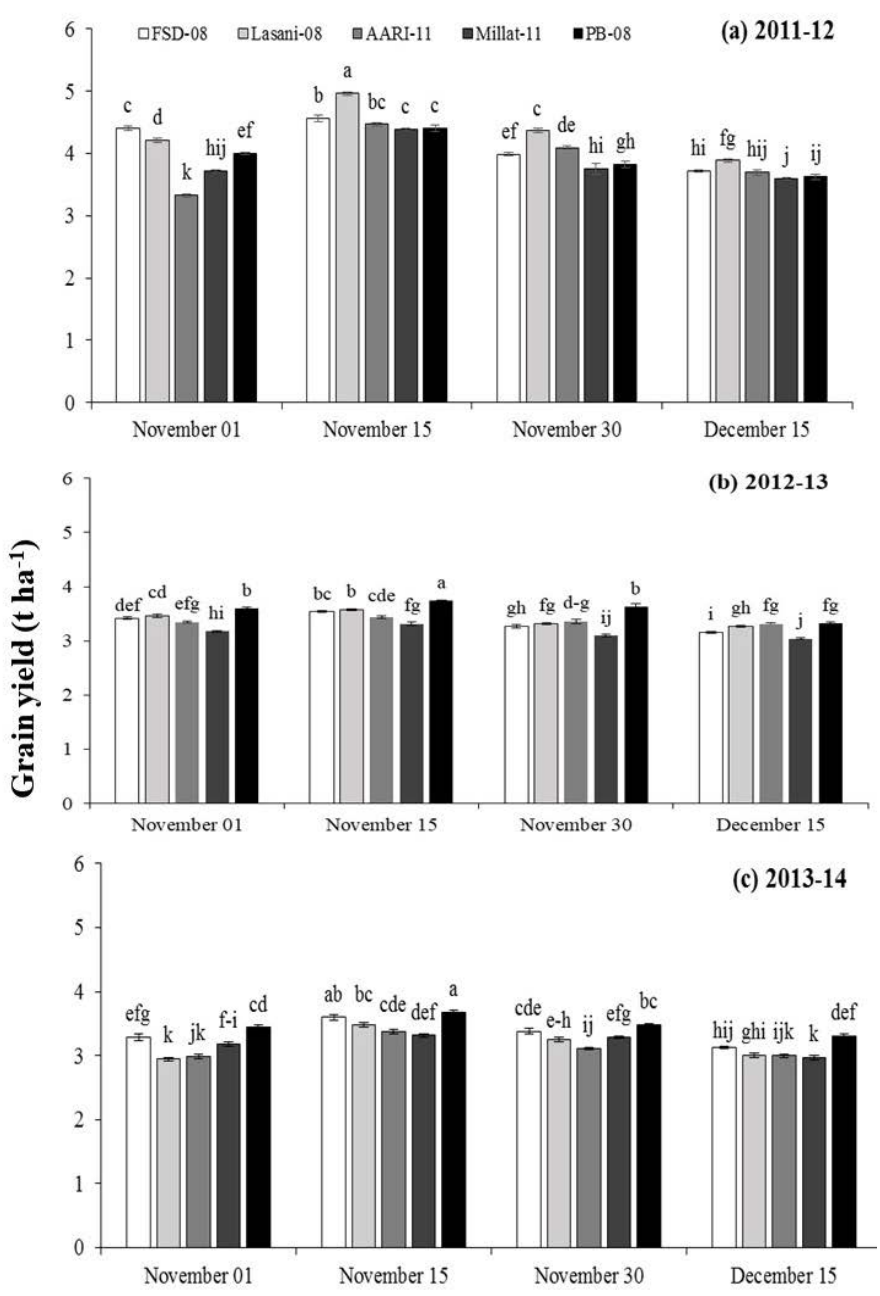

Figure 1: Effect of sowing time on grain yield of wheat. Bars are mean $\pm S E$ of three replications. Bars sharing same letter don't differ significantly.

Varieties of wheat differed regarding yield and yield formation in response to sowing time. Among different varieties the Lasani-08 and PB-11 both were high yielders (Figure 1). Higher grain yield of Lasani-08 and PB-11 was associated with higher tiller density and grains number per spike, respectively (Table 2). Grain yield of AARI-11 was least affected by sowing time (Figure 1) which was also manifested by regression analysis i.e. only 1000-grain weight had significant negative relation with sowing time (Figures 2 and 3). The present study results showed that Millat-11 was low yielder and highest decline in its yield occurred because of late sowing which was due to greater decrease in tillers per $\mathrm{m}^{2}$ (Table 2, Figure 1). Previous studies have shown that different varieties of wheat differ in yield formation and yield in response to sowing time (Kelley, 2001; Tapley et al., 2013). 

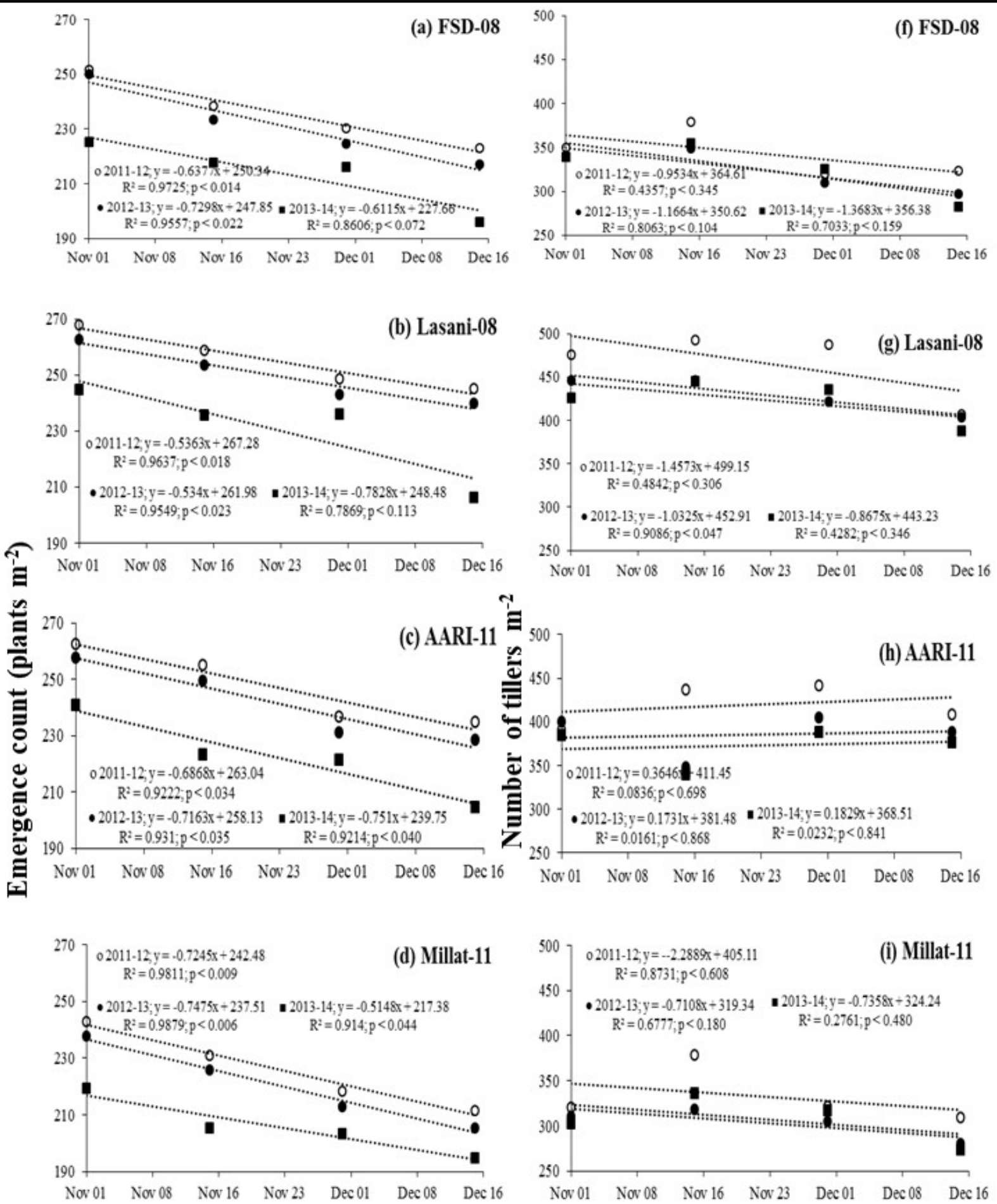

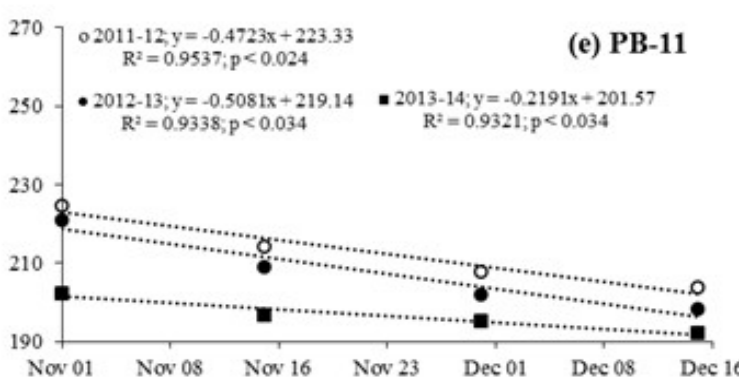

Sowing time

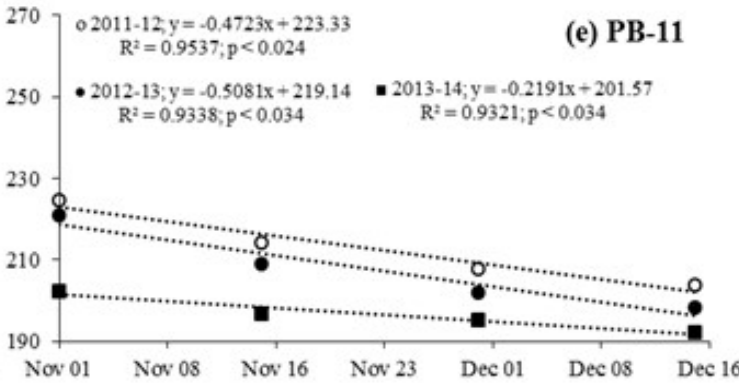

Sowing time

Figure 2: Relationship between ( $a-e)$ sowing time and emergence count (plants $m-2)$, and $(f-j)$ sowing time and number of tillers $m$-2 during 2011-12 to 2013-14. Coefficients of determination (R2), significance of coefficients $(P<0.05)$ and dependence of (a-e) emergence count $m-2(y)$ and $(f-g)$ number of tillers $m-2(y)$ on sowing time $(x)$ are given $(n=4)$. 

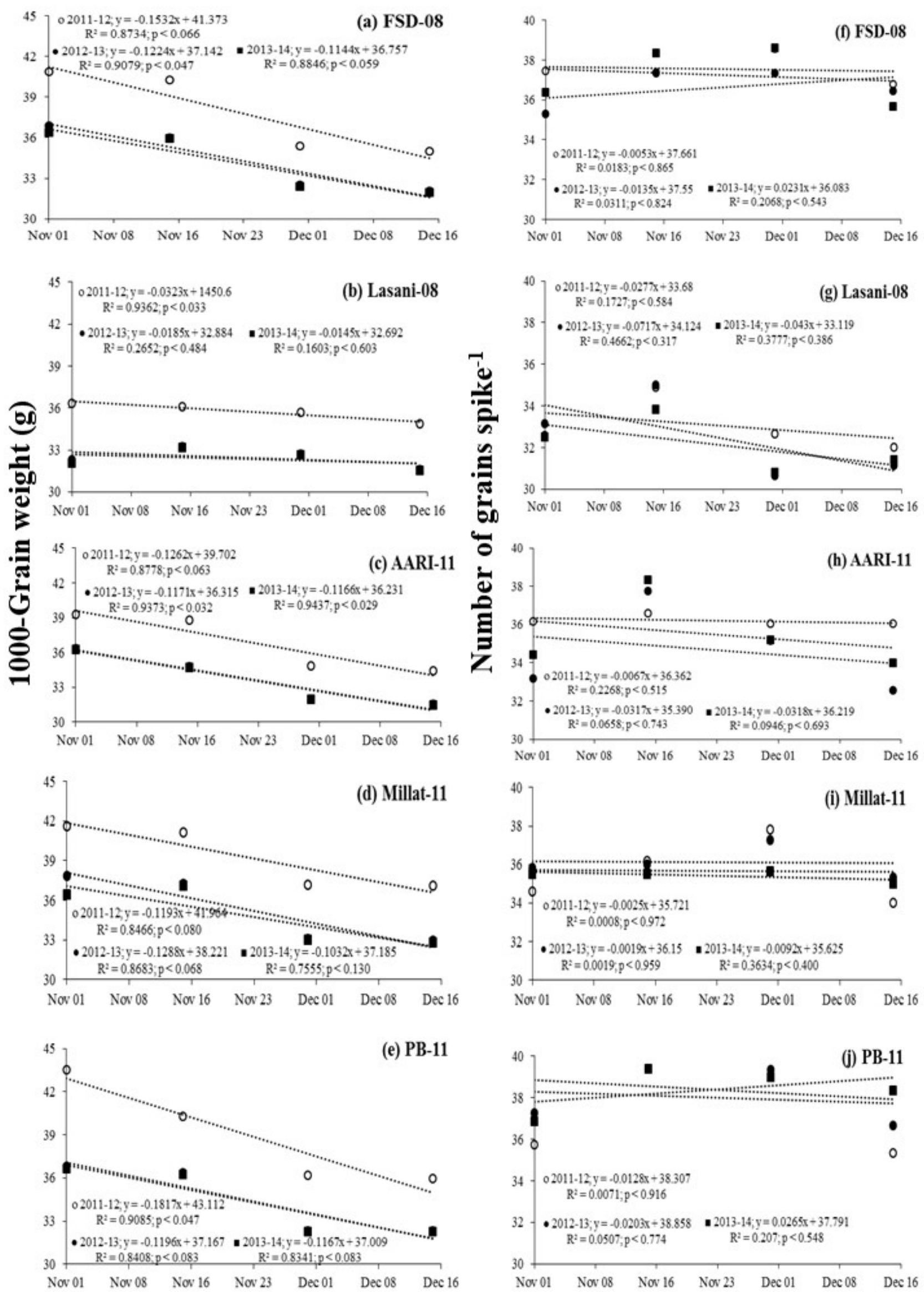

Sowing time

Sowing time

Figure 3: Relationship between (a-e) sowing time and 1000-grain weight $(g)$, and $(f-j)$ sowing time and number of grains spike-1 during 2011-12 to 2013-14. Coefficients of determination $\left(R^{2}\right)$, significance of coefficients $(P<0.05)$ and dependence of $(a-e) 1000$-grain weight $(y)$ and $(f-g)$ number of grains spike-1 $(y)$ on sowing time $(x)$ are given $(n=4)$. 
Table 3: Pearson's coefficients of correlation between yield attributes (emergence count, number of tillers $m^{-2}$, 1000-grain weight and number of grains spike ${ }^{-1}$ ) and grain yield as influenced by sowing time.

\begin{tabular}{|c|c|c|c|c|c|c|}
\hline \multirow[t]{2}{*}{ Year } & \multirow[t]{2}{*}{ Variables } & \multicolumn{5}{|c|}{ Grain yield $\left(t h^{-1}\right)$} \\
\hline & & FSD-08 & Lasani-08 & AARI-11 & Millat-11 & PB-11 \\
\hline \multirow[t]{4}{*}{ 2011-12 } & Emergence count $\mathrm{m}^{-2}$ & $0.8140^{\text {ns }}$ & $0.3656^{\mathrm{ns}}$ & $-0.1984^{\mathrm{ns}}$ & $0.3274^{\mathrm{ns}}$ & $0.5339^{\text {ns }}$ \\
\hline & Number of tillers $\mathrm{m}^{-2}$ & $0.9016^{*}$ & $0.7912^{\mathrm{ns}}$ & $0.9260^{*}$ & $0.9995^{* *}$ & $0.8073^{\text {ns }}$ \\
\hline & 1000-grain weight (g) & $0.9510^{* *}$ & $0.6158^{\mathrm{ns}}$ & $-0.0486^{\mathrm{ns}}$ & $0.5592^{\mathrm{ns}}$ & $0.5993^{\text {ns }}$ \\
\hline & Number of grains spike ${ }^{-1}$ & $0.0719^{\mathrm{ns}}$ & $0.9734^{* *}$ & $0.6238^{\text {ns }}$ & $0.3426^{\mathrm{ns}}$ & $0.5886^{\mathrm{ns}}$ \\
\hline \multirow[t]{4}{*}{$2012-13$} & Emergence count $\mathrm{m}^{-2}$ & $0.6961^{\mathrm{ns}}$ & $0.7661^{\mathrm{ns}}$ & $0.4655^{\mathrm{ns}}$ & $0.6426^{\mathrm{ns}}$ & $0.4908^{\text {ns }}$ \\
\hline & Number of tillers $\mathrm{m}^{-2}$ & $0.9822^{* *}$ & $0.9228^{*}$ & $-0.8019^{\mathrm{ns}}$ & $0.8647^{\text {ns }}$ & $0.5862^{\mathrm{ns}}$ \\
\hline & 1000-grain weight (g) & $0.8837^{\mathrm{ns}}$ & $0.7569^{\mathrm{ns}}$ & $0.4334^{\mathrm{ns}}$ & $0.7859^{\mathrm{ns}}$ & $0.6008^{\text {ns }}$ \\
\hline & Number of grains spike ${ }^{-1}$ & $0.4624^{\mathrm{ns}}$ & $0.9686^{\prime \prime}$ & $0.9642^{* *}$ & $0.0140^{\mathrm{ns}}$ & $0.8491^{\text {ns }}$ \\
\hline \multirow[t]{4}{*}{ 2013-14 } & Emergence count $\mathrm{m}^{-2}$ & $0.5743^{\mathrm{ns}}$ & $0.2326^{\mathrm{ns}}$ & $-0.0075^{\mathrm{ns}}$ & $0.4296^{\mathrm{ns}}$ & $0.2905^{\text {ns }}$ \\
\hline & Number of tillers $\mathrm{m}^{-2}$ & $0.8667^{\mathrm{ns}}$ & $0.7057^{\mathrm{ns}}$ & $-0.8819^{\mathrm{ns}}$ & $0.9620^{*}$ & $0.5527^{\text {ns }}$ \\
\hline & 1000 -grain weight (g) & $0.5311^{\mathrm{ns}}$ & $0.9156^{*}$ & $0.1736^{\text {ns }}$ & $0.4957^{\mathrm{ns}}$ & $0.5801^{\text {ns }}$ \\
\hline & Number of grains spike ${ }^{-1}$ & $0.5617^{\mathrm{ns}}$ & $0.4606^{\mathrm{ns}}$ & $0.9911^{*+*}$ & $0.9345^{*}$ & $0.5293^{\mathrm{ns}}$ \\
\hline
\end{tabular}

n: 4; "“"p<0.01; $p<0.05 ; " p<0.10$; ns: non-significant.

\section{Critical yield determining trait}

Linear regression revealed that sowing time variably affected the emergence and yield traits of different varieties of wheat during all the years (Figures 2 and 3 ). There was significant negative linear relation between sowing time and emergence count of all varieties of wheat (Figure 2). Significant negative linear relationship existed between sowing time and tillers $\mathrm{m}^{-2}$ of Lasani-08 during 2012-13, and PB-11 during all the years (Figure 2). In addition, a significant linear negative relationship existed between sowing time and 1000-grain weight of FSD-08 during 2012-13, Lasani-08 during 2011-12, AARI-11 during 201213 and 2013-14, and PB-11 during 2011-12 (Figure 2). However, non-significant relation of sowing time with grains number of wheat varieties existed during all the years (Figure 2).

The correlation analysis manifested a positive correlation of tillers $\mathrm{m}^{-2}$ with grain yield of FSD-08 during 2011-12 (p 0.1) and 2012-13 (p 0.05) as well as 1000-grain weight and yield during 2011-12 (p 0.05) (Table 3). For Lasani-08, positive correlation existed between tillers $\mathrm{m}^{-2}$ and yield during 2012-13 (p 0.1), 1000-grain weight and yield during 2013-14 ( $\mathrm{p} 0.1$ ), and number of grains per spike and grain yield duirng 2011-12 and 2012-13 (p 0.05) (Table 3). A positive correlation of tillers $\mathrm{m}^{-2}$ with grain yield of AARI-11 was noticed during 2011-12 (p 0.1) as well as grains per spike with grain yield duirng 2012-13 (p 0.05) and 2013-14 (p 0.01) (Table 3). Likewise, there was positive correlation of tillers $\mathrm{m}^{-2}$ with grain yield during 2011-12 (p 0.05) and 2013-14 (p 0.05) as well as grains number and yield (p 0.1) of Millat-11 duirng 2013-14 (Table 3). However, no significiant correlation was noticed between any yield related trait and grain yield of PB-11 during all the years (Table 3).

In present study, sowing time had negative relation with emergence of all varieties, tillers of Lasani-08 and PB-11 (Figure 2), and 1000-grain weight of FSD-08, Lasani-08, AARI-11 and PB-11 (Figure 3) while non-significant relation with grains per spike of all varieties (Figure 3) indicating that the greatest losses occurred to emergence and grain weight among yield traits due to temporal fluctuation in sowing and it was followed by number of tillers. GomezMacPherson and Richards (1995) reported negative relation between sowing time and grain weight. Blue et al. (1990) recorded that contribution of grain weight in estimation of yield was increased as sowing delayed. Similarly, Tapley et al. (2013) described that sowing dates had negative relationship with spikes (tillers) $\mathrm{m}^{-2}$, grain weight and grains number per spike of wheat. In present study, grain yield was correlated positively with the number of tillers of FSD-08, Lasani-08, AARI11 and Millat-11, the grain weight of FSD-08 and Lasani-08, and the number of grains of Lasani-08, AARI-11 and Millat-11 in different years (Table 3 ). These relationships manifested that the number of tillers followed by grains per spike were the most critical yield imparting traits in these varieties. Similar relations of yield traits with grain yield of wheat have been reported by Tapley et al. (2013). 
Conclusions and Recommendations

Present study showed that sowing on November 01 and after November 15 decreased yield, emergence and yield related attributes of all wheat varieties. Number of tillers and 1000-grain weight were most affected traits of wheat varieties due to sowing dates. However, yield of different varieties was variably affected mainly by number of tillers followed by grains per spike under the influence of sowing dates. In conclusion, sowing on November 15 produced highest yield and number of tillers was critical yield determining component followed by grains per spike in response to sowing dates.

\section{Author's Contributions}

Javed Iqbal conducted experiment. Ali Zohaib performed statistical data analysis, prepared the write up and did overall management of article. Muzzammil Hussain supervised the study and gave technical input at every step. Iftikhar Ahmad helped in abstract and conclusion. Adnan Bashir managed crop in field. Wardah Muzaffer helped in data collection. Naeem Faisal collected literature. Muhammad Tahir Latif helped in data analysis. Sami Ullah helped in data management.

\section{Conflict of interest}

The authors have declared no conflict of interest.

\section{References}

Akhtar, M., R.M. Iqbal, M. Jamil and L.H. Akhtar. 2012. Effect of sowing date on emergence, tillering and grain yield of different wheat varieties under Bahawalpur conditions. Pak. J. Agric. Sci. 49(3): 255-259.

Arduini, I., L. Ercoli, M. Mariotti and A. Masoni. 2009. Sowing date affect spikelet number and grain yield of durum wheat. Cereal Res. Commun. 37(3): 469-478. https://doi. org/10.1556/CRC.37.2009.3.16

Bagulho, A.S., R. Costa, A.S. Almeida, N. Pinheiro, J. Moreira, C. Gomes, J. Coutinho, A. Costa, J. Coutinho and B. Maçãs. 2015. Influence of year and sowing date on bread wheat quality under Mediterranean conditions. Emirates J. Food Agric. 27: 186-199. https://doi.org/10.9755/ ejfa.v27i2.19279

Baloch,M.S., I.T.H. Shah, M.A. Nadim,M.I. Khan and A.A. Khakwani. 2010. Effect of seeding density and planting time on growth and yield attributes of wheat. J. Anim. Plant Sci. 20(4): 239-240.

Barnabás, B., K. Jäger and A. Fehér. 2008. The effect of drought and heat stress on reproductive processes in cereals. Plant Cell Environ. 31(1): 11-38.

Bassu, S., F. Giunta and R. Motzo. 2010. Effects of sowing date and cultivar on spike weight and kernel number in durum wheat. Crop Past. Sci. 61(4): 287-295. https://doi.org/10.1071/ CP09235

Blue, E.N., S.C. Mason and D.H. Sander. 1990. Influence of planting date, seeding rate, and phosphorus rate on wheat yield. Agron. J. 82(4): 762-768. https://doi.org/10.2134/agronj1990. $00021962008200040022 x$

Farooq, M., S.M.A. Basra, H. Rehman and B.A. Saleem. 2008. Seed priming enhances the performance of late sown wheat (Triticum aestivum L.) by improving chilling tolerance. J. Agron. Crop Sci. 194(1): 55-60. https://doi. org/10.1111/j.1439-037X.2007.00287.x

Friend, D.J.C., 2011. Tillering and leaf production in wheat as affected by temperature and light intensity. Can. J. Bot. 43(9): 1063-1076. https:// doi.org/10.1139/b65-123

Fujisaka, S., L.W. Harrington and P.R. Hobbs. 1994. Rice-wheat in South Asia: cropping systems and long term priorities established through diagnostic research. Agric. Syst. 46(2): 169-187. https://doi.org/10.1016/0308521X(94)90096-X

Gomez-MacPherson, H. and R.A. Richards. 1995. Effect of sowing time on yield and agronomic characteristics of wheat in southeastern. Aust. J. Agric. Res. 46(7): 1381-1399. https://doi. org/10.1071/AR9951381

Houghton, J.T., Y. Ding, D.J. Griggs, M. Noguer, P.J. Linden and D. Xiaosu. 2001. Climate change: The scientific basis contribution of working group first to third assessment report of the intergovernmental panel on climate change. Cambridge University Press, UK.

Hussain, M., G. Shabir, M. Farooq, K. Jabran and S. Farooq. 2012a. Developmental and phenological responses of wheat to sowing dates. Pak. J. Agric. Sci. 49(4): 1-10.

Hussain, M., M. Farooq, G. Shabir, M.B. Khan, A.B. Zia and D.J. Lee. 2012b. Delay in planting 
decreases wheat productivity. Int. J. Agric. Biol. 14(4): 533-539.

Inamullah, N.H., Z.H. Shah and F.U. Khan. 2007. An analysis of the planting dates effect on yield and yield attributes of spring wheat. Sarhad J. Agric. 23(2): 269-275.

Jame, Y.W. and H.W. Cutforth. 2004. Simulating the effects of temperature and seeding depth on germination and emergence of spring wheat. Agric. For. Met. 124(3-4): 207- 218. https:// doi.org/10.1016/j.agrformet.2004.01.012

Karim, M.A., A. Hamid and M.S. Rahman. 1999. Grain growth and yield performance of wheat under subtropical conditions: I. effect of sowing dates. Cereal Res. Commun. 27: 439-446. https://doi.org/10.1007/BF03543561

Kelley, K.W., 2001. Planting date and foliar fungicide effects on yield components and grain traits of winter wheat. Agron. J. 93(2): 380-389. https://doi.org/10.2134/agronj2001.932380x

Lan, X., Y. Chai, R. Li, B. Li, H. Cheng, L. Chang and S. Chai. 2018. Effect of sowing quantity on soil temperature and yield of winter wheat under straw strip mulching in arid region of northwest China. IOP Conf. Ser. Earth Environ. Sci. 108(4): 042058. https://doi. org/10.1088/1755-1315/108/4/042058

Luo, Q. G. O'Leary,J. Cleverly and D.Eamus.2018. Effectiveness of time of sowing and cultivar choice for managing climate change: wheat crop phenology and water use efficiency. Int. J. Biometeor. 62(6): 1049-1061. https://doi. org/10.1007/s00484-018-1508-4

Mohammed, A.R. and L. Tarpley. 2010. Effects of high night temperature and spikelet position on yield-related parameters of rice (Oryza sativa L.) plants. Eur. J. Agron. 33(2): 117-123. https://doi.org/10.1016/j.eja.2009.11.006

Ortiz-Monasterio, J.I., S.S. Dhillon and R.A. Fischer. 1994. Date of sowing effects on grain-yield and yield components of irrigated spring wheat cultivars and relationships with radiation and temperature in Ludhiana, India. Field Crops Res. 37(3):169-184. https://doi. org/10.1016/0378-4290(94)90096-5

Prasad, P.V.V., S.R. Pisipati, Z. Ristic, U. Bukovnik and A. Fritz. 2008. Impact of night-time temperature on physiology and growth of spring wheat. Crop Sci. 48(6): 2372-2380. https://doi. org/10.2135/cropsci2007.12.0717

Qasim, M., M. Qamar, F. Ullah and M. Alam.
2008. Sowing dates effect on yield and yield components of different wheat varieties. J. Agric. Res. 46(2): 45-48.

Sacks, W.J., D. Deryng, J.A. Foley and N. Ramankutty. 2010. Crop planting dates: an analysis of global patterns. Glob. Ecol. Biogeogr. 19(5): 607-620. https://doi.org/10.1111/ j.1466-8238.2010.00551.x

Sandhu, S.S., P. Kaur, K.K. Gill and B.B. Vashisth. 2019. The effect of recent climate shifts on optimal sowing windows for wheat in Punjab, India. J. Water Clim. Change. https://doi. org/10.2166/wcc.2019.241

Shah, M.A., M. Farooq, M. Shahzad, M.B. Khan and M. Hussain. 2017. Yield and phenological responses of BT cotton to different sowing dates in semi-arid climate. Pak. J. Agric. Sci. 54(2): 233-239. https://doi.org/10.21162/ PAKJAS/17.4394

Silva, R.R., G. Benin, J.L. de Almeida, I.C.B. Fonseca and C. Zucareli. 2014. Grain yield and baking quality of wheat under different sowing dates. Acta Sci. Agron. 36(2): 201-210. https:// doi.org/10.4025/actasciagron.v36i2.16180

Steel, R.G.D., J.H. Torrie and D.A. Deekey. 1997. Principles and procedures of statistics: a biometrical approach, $3^{\text {rd }}$ Ed. McGraw Hill Book Co. Inc. New York. pp. 400-428.

Sun, H., X. Zhang, S. Chen, D. Pei and C. Liu. 2007. Effects of harvest and sowing time on the performance of the rotation of winter wheatsummer maize in the North China Plain. Ind. Crops Prod. 25(3): 239-247. https://doi. org/10.1016/j.indcrop.2006.12.003

Tahir, S., A. Ahmad, T. Khaliq and M.J.M. Cheema. 2019. Evaluating the impact of seed rate and sowing dates on wheat productivity in semiarid environment. Int. J. Agric. Biol. 22(1): 5764.

Tapley, M., B.V. Ortiz, E. van Santen, K.S. Balkcom, P. Mask and D.B. Weaver. 2013. Location, seeding date, and variety interactions on winter wheat yield in southeastern United States. Agron. J., 105(2): 509-518. https://doi. org/10.2134/agronj2012.0379

Thorne, G.N. and D.W. Wood. 1987. Effects of radiation and temperature on tiller survival, grain number and grain yield in winter wheat. Ann. Bot. 59(4): 413-426. https://doi. org/10.1093/oxfordjournals.aob.a087330

Wajid, A., A. Hussain, A. Ahmad, A.R. Goheer, M. 
Ibrahim and M. Mussaddique. 2004. Effect of sowing date and plant population on biomass, grain yield and yield components of wheat. Int. J. Agric. Biol. 6: 1003-1005.

Wallwork, M.A.B., S.J. Logue, L.C. MacLeod and
C.F. Jenner. 1998. Effect of high temperature during grain filling on starch synthesis in the developing barley grain. Funct. Plant Biol. 25(2): 173-181. https://doi.org/10.1071/ PP97084 